\title{
AZ INTÉZMÉNYI MÜKÖDÉSI KERETEK ÁTALAKÍTÁSI KÍSÉRLETEI A MAGYAR FELSŐOKTATÁSBAN
}

\author{
DERÉNYI ANDRÁS
}

\begin{abstract}
A felsőoktatási intézmények szerepváltozásai, a harmadik misszió feltűnése és erősödése és az ezeknek megfelelő vagy ezekhez igazodó irányítási megoldások, működési keretek, az állam és a felsőoktatási intézmények viszonyának alakulása több évtizede témája a felsőoktatás-politika változásával, az irányítás kérdéseivel foglalkozó kutatóknak, szerzőknek (Clark 1983; Etkowitz 1997; Clark 1998; van Vaught-de Boer 2015; GronitzkaMassen-de Boer 2017, hogy csak néhány ismertebbre utaljunk). A hazai kutatókat is foglalkoztatta ez a témakör (Barakonyi, Hrubos, Keczer, Kováts, Polónyi számos írása), ami bőséges muníciót ad a kutatásra, ugyanis az irányítás és az intézményi státus kérdéseivel rendre együtt járnak az intézmények kormányzásának, vezetési struktúrájának és finanszírozásának a kérdései is. ${ }^{1} \mathrm{~A} z$ intézményi müködési keretek alakítására irányuló magyar felsőoktatás-politikai törekvések hosszabb időszakot átfogó áttekintésére azonban csak kevesen vállalkoztak (Polónyi 2009; Veres 2016a, 2016b). Jelen írás arra tesz kíséreltet, hogy áttekintse az elmúlt három évtized törekvéseit és fejleményeit e téren, keresve a jellegzetes azonosságokat vagy épp sajátos különbségeket.
\end{abstract}

Kulcsszavak: modellváltás, jogi státus, müködési keretek, gazdálkodási szabadság, autonómia, felsőoktatás-politika és implementáció

Changes in the role of higher education institutions, the emergence and strengthening of their third mission, and the development of appropriate or responsive way of governance, operational frameworks, and the relationship between the state and higher education institutions have been a topic for decades for researchers and authors (Clark 1983; Etkowitz 1997; Clark 1998; van Vaught-de Boer 2015; Gronitzka-Massen-de Boer 2017 just to name a few). Hungarian researchers were also interested in this topic (several paper of Barakonyi, Hrubos, Keczer, Kováts, Polónyi), which provides further resources for research; indeed, issues of steering and status of institutions go hand in hand with issues of governance, management structure, and financing of institutions. However, only a few scholars (Polónyi 2009; Veres 2016a, 2016b) have undertaken a long-term

Levelező szerző: Derényi András, Budapest, E-mail: andras@derenyi.net

1 Bár magától értetődő, hogy az intézményi működés külső jogi, formai kereteivel összefüggenek a belső elemek (a kormányzás, a vezetési struktúra, a finanszírozás), ez utóbbiakkal jelen írás csak érintőlegesen foglalkozik, mert e lapszám más tanulmányai részletesen szólnak róluk. 
review of the Hungarian higher education policy aspirations for the development of institutional operating frameworks. This paper attempts to look at those aspirations and developments that have been done in the past three decades, searching for distinctive identities or even specific differences.

Keywords: changes in the role of HEIs, legal frameworks of operation, freedom in management, autonomy, higher-education policy, policy implementation

\section{A 90-es évek ${ }^{2}$}

B ár a közvélemény figyelmét az elmúlt év elsősorban a Budapesti Corvinus Egyetem jogi státusának és gazdálkodási rendjének átalakításával kapcsolatos kormányzati döntései és intézkedései irányították rá az intézményi müködési keretek kérdéseire, a magyar felsőoktatás-politika már igen korán, közvetlenül a rendszerváltást követően gondolkodni kezdett a felsőoktatási intézmények megfelelő jogállásának kialakításán. Nem volt ugyanis magától értetődő a költségvetési intézményként történő működtetés a tulajdonviszonyok jelentős átalakulásának idején. Az 1993-ban elfogadott felsőoktatási törvényt ${ }^{3}$ előkészítő koncepció (Király et al. 1991, idézi Veres 2016a) felvetette az egyetemek számára a köztestületi vagy alapítványi tulajdonformát, amely akár a tulajdonviszonyok rendezése, akár az önálló gazdálkodás biztosítása érdekében megfelelőnek tűnt. Az elfogadott törvény végül ezeket nem vezette be.

A törvény előkészítése során az a döntés született, hogy a felsőoktatás fejlesztésével kapcsolatos kérdéseket egy külön jogszabályba foglalják (ez lett volna a felsőoktatásfejlesztési törvény vagy kormányrendelet). Ennek koncepciója (MKM 1994) tartalmazta egyetemi, főiskolai központok létrehozását „saját tulajdonnal rendelkező közalapítványi formában és teljes gazdálkodási önállósággal”. Ám végül nem született sem törvény, sem rendelet a fejlesztésről. A kormány előterjesztésére az Országgyűlés fogadott el egy határozatot ${ }^{4}$ a felsőoktatás fejlesztésének irányelveiről. Ez azt javasolta, hogy „hosszabb távon ki kell dolgozni a közalapítványi tulajdonba adás feltételeit, hogy mód nyíljék a ráfordításigény mérséklésére és központi költségvetési támogatáson túli források fokozottabb bevonására. [...] Bővíteni kell az önálló intézményi gazdálkodás közgazdasági és jogi kereteit..." (9. pont; kiemelés az eredetiben.) A határozat emellett az intézményi gazdálkodás önállóságának bővítését és a szervezeti és vezetési struktúra korszerüsítését sürgette.

Az országgyülési határozat nyomán szakértői anyagok készültek a minisztérium számára (Price Waterhouse 1995; Geréby et al. 1995), amelyek szintén a közalapítványi konstrukciót szorgalmazták. Az előbbi a vegyes finanszírozás (az állami szerepvállalás szükülésével az intézményi saját bevételek növelése, ingatlanok nem oktatási célú hasz-

Az itt következő áttekintésben évtizedes bontást alkalmazunk. A magyar felsőoktatás legújabb kori történeti szakaszolásának hátteréhez részletesen lásd: Derényi-Temesi 2016 (szerkesztői bevezetö) és Temesi 2016, ugyanott.

3 1993. évi LXXX. törvény a felsőoktatásról

4 07/1995. (XI. 4.) OGY határozat a felsőoktatás fejlesztésének irányelveiről 
nosítása, szponzoráció és magánerő bevonása a felsőoktatás finanszírozásába) körülményei között a jobb intézményi gazdálkodás lehetővé tételével, az utóbbi a jogi értelemben vett önállóság biztosításával és az önálló cselekvés és felelősségvállalás lehetőségével indokolta a javaslatot.

1996. július 3-án az Országgyülés az 1993-as törvény jelentős módosítását hajtotta végre. ${ }^{5}$ A fenti javaslatok azonban nem jelentek meg a törvényben, mi több, a jogszabály egyértelművé tette, hogy „az állami felsőoktatási intézmény költségvetési szerv, amely kincstári vagyonnal, a központi költségvetés meghatározott előirányzataiból, valamint más kiegészítő forrásokkal gazdálkodik" (1.§. (2) bek.). Polónyi (2009) szerint ekkorra „eldőlt a felsőoktatási intézmények tulajdonosi és gazdasági autonómiájának kérdése”.

Ezeket az éveket az intézményintegrációkkal kapcsolatos tervek, ötletek, felvetések uralták: az oktatáspolitika alakítói keresték azokat a megoldásokat, amelyekkel minél kisebb megrázkódtatással integrálható nagy regionális felsőoktatási központokká a széttagolt, kisméretű intézményekből álló hálózat. Részben ennek támogatására is szolgált volna a Világbanktól felvenni tervezett kölcsön, amelynek előkészítő munkálatai már javában folytak. 1997-ben a Müvelődési és Közoktatási Minisztérium megjelentette a felsőoktatás fejlesztésének középtávú stratégiáját (MKM 1997), ami alcíme szerint „az 1998-ban kezdődő felsőoktatási reform program szektorfejlesztési stratégiája, amely a Világbankhoz benyújtott fejlesztési támogatási pályázat meghatározó politikai dokumentuma". Az integrációban pionír szerepet vállaló intézmények (három kísérleti integrációt terveztek ekkortájt) számára a dokumentum mintegy mézesmadzagként - az 1996-os törvénymódosítás fent idézett határozott rendelkezései ellenére - felveti a nagyobb gazdálkodási szabadság biztosítását, az intézményirányítás és -müködtetés fennálló formáinak bővítését. Az országgyülési határozatra visszautalva újra felveti a „szervezeti korszerűsítés minden külső és belső formájának” ösztönzését (C.9. pont). A kormányzati stratégiai lépések között pedig előrevetíti, hogy amennyiben „a három kísérleti intézménynél a nagyobb pénzügyi önállóság kapcsán felmerült tapasztalatok pozitívak lesznek, e tapasztalatok elemzése alapján, az integrációs programban részt vevő összes többi intézményre is kiterjesztenénk a nagyobb gazdálkodási autonómiát" (D.19. pont).

$\mathrm{A} z$ országgyülési határozat és az annak megvalósítására kormányhatározatban ${ }^{6} \mathrm{ki}$ adott feladatterv és jogalkotási program megvalósulásáról készült minisztériumi összefoglaló (MKM 1998) a közalapítványi formájú működés és az önálló vagyonhoz juttatás kapcsán azt jelentette, hogy a kérdést a „felsőoktatási intézmények gazdálkodási és szakmai tevékenységének átláthatóságát és elszámoltathatóságát eredményező gazdálkodási és vezetési rendszer kialakításáig [...] levette a napirendről”. Ugyanakkor a kísérleti intézmények esetében a „gazdálkodási önállóság fokozásával, amellyel a PM is egyetért, fokozatosan megkezdhető a később pontosítandó formájú gazdaságilag is autonóm szervezethez vezető körültekintő átmenet".

Végül a „körültekintő átmenetből” sem lett semmi. A felsőoktatás-irányítás figyelmét a következő években az intézményrendszer átalakítása (amit az 1999-ben kiadott integ-

1996. évi LXI. törvény a felsőoktatásról szóló 1993. évi LXXX. törvény módosításáról

1049/1996. (V. 22.) Kormányhatározat a felsőoktatás fejlesztésének irányelveiről szóló 107/1995. (XI. 4.) OGY határozat végrehajtását szolgáló feladattervről és jogalkotási programról 
rációs törvény ${ }^{7}$ fémjelez), jelentős infrastrukturális beruházások elindítása, valamint az intézményi stratégiai tervezés alapjainak lerakása (az első intézményfejlesztési tervek elkészítése) kötötte le.

\section{A 2000-es évek}

2003-ban azonban ismét előkerült a működési keretek és az intézmények jogi státusának átalakítása. A 2002 szeptemberében az Oktatási Minisztérium által elindított Csatlakozás az Európai Felsőoktatási Térséghez című programban előbb egy felsőoktatás-fejlesztési alapkoncepció született (OM 2002), majd 13 szakértői csoport kezdett dolgozni annak részletes kibontásán. ${ }^{8} \mathrm{~A} z$ intézményi működés kérdéseivel foglalkozó munkacsoportban ismét felmerült az intézmények nagyobb gazdasági autonómiával való felruházása. Számos lehetőség (speciális költségvetési intézmény, társasági forma, nonprofit szervezet) részletes elemzése nyomán (Szalai 2004) a fejlesztési koncepció egyik utolsó változata (CSEFT 2003) az intézmények által választható két alternatív megoldást dolgozott ki: az államháztartás rendszerén belül kialakítandó sajátos jogállású, speciális költségvetési intézményt, illetve az állam által alapított közhasznú társaság fenntartásában müködő intézményt. Az intézményi müködés átalakítására irányuló elképzelések Polónyi (2009) összefoglalása szerint arra irányultak, hogy növekedjen a gazdasági autonómia, a közpénzek és a közvagyon hatékonyabb kezelésének képessége, valamint a rugalmasabb, piacszerübb müködés lehetősége. Ennek meghatározó eleme volt a költségvetési intézményi státusz átalakítása speciális felsőoktatási intézményi státusszá, amely nem (vagy csak részben) tartozik az államháztartási törvény, a közalkalmazotti törvény, továbbá a kincstár hatálya alá; valamint új vezetési struktúra kialakítása, az intézményi belső szervezet szabadabb átalakítási lehetőségének megteremtése, a menedzsment hatásköreinek erősítése.

A koncepcióban foglalt javaslatok a politikai viták és a felsőoktatási érdekképviseletekkel lefolytatott alkuk nyomán felpuhultak (erről lásd Barakonyi 2009: 101). A Magyar Universitas Program néven nyilvánossá vált dokumentumban, amely egyben egy új felsőoktatási törvény koncepciója is volt (MUP 2004a), már csak egyes elemei maradtak meg. A MUP-ban csak a speciális jogállású költségvetési szerv mint működési forma (jogállás) jelent meg (utalással arra, hogy ez a forma megfelel a polgári törvénykönyv módosítására vonatkozó kormányzati koncepcióban szereplő közintézményi státusnak). E speciális státust azonban csak több feltételnek is megfelelő felsőoktatási intézmények nyerhették volna el. A két hónappal később, már az Oktatási Minisztérium és az Igazságügyi Minisztérium közös elöterjesztésével a Kormány elé került változat (MUP 2004b) még puhábban fogalmazott, speciális jogosítványokkal rendelkező költségvetési szerv definiálását javasolta, az indoklásban pedig új érvként került elő a teljesítményösztönzés, a gazdasággal való kapcsolat erősítése, az oktatók, kutatók, hallgatók saját vállalkozásainak campus területére történő telepítésének lehetősége. A dokumentum elején ugyanakkor már ott állt a Pénzügyminisztériumnak a gazdasági önállóság növelésével szembeni elutasító véleménye. A PM álláspontja szerint „a költségvetési szervként működő felső-

1999. évi LII. törvény a felsőoktatási intézményhálózat átalakításáról, továbbá a felsőoktatásról szóló 1993. évi LXXX. törvény módosításáról

8 A CSEFT történetéről, utóéletéről és recepciójáról részletes áttekintés és elemzés született (Szolár 2010). 
oktatási intézmények már jelenleg is túl nagy gazdálkodási szabadsággal rendelkeznek". A 2005. november végén elfogadott új felsőoktatási törvény azonban az állam által alapított felsőoktatási intézményeket ismét költségvetési szervként definiálta (7.\$. (3) bek.), azaz ezúttal sem született új intézményi státus. A kormányzási struktúra átalakítására tett kezdeményezés pedig az Alkotmánybíróság elutasításába ${ }^{9}$ ütközött.

A CSEFT keretében felbukkant javaslat - az államháztartás rendszerén belül egy sajátos jogállás létrehozása - azonban hamarosan általános érvénnyel jelent meg újra. 2008 decemberében fogadta el az Országgyúlés az ún. státustörvényt (Kt.), ${ }^{10}$ amelyben minden költségvetési szervre vonatkozóan három különböző típust definiált: a közintézményt, a közintézetet és a vállalkozó közintézetet. A törvény azt is meghatározta, hogy az irányító szerv (a felsőoktatás esetén az Oktatási Minisztérium) a következő év június 1-jéig köteles besorolni az intézményeket valamelyik típusba: alapesetben a közintézmény típusba. A felsőoktatási törvény módosításával azonban azt is kimondták, hogy a felsőoktatási intézmények kezdeményezhetik vállalkozói közintézetté való átsorolásukat bizonyos feltételek fennállása esetén. A Kt. 100/J. §-a sorolta a vállalkozói közintézet jogosítványait, amelyek kiterjedtek az előirányzatok korlátozások nélküli felhasználására, az év végi maradvány felhasználására (elvonásának tilalmára), a vállalkozási maradvány (eredmény) saját tulajdonná válására, a vagyon feletti tulajdonosi jogok gyakorlására (értékmegőrzés mellett), a vagyonnal való önálló gazdálkodásra, a vagyon értékének öszszesen legfeljebb 50\%-os mértékéig hitel felvételére. Ezek olyan elemek, amelyek a felsőoktatási intézmények működési kereteinek megváltoztatásáról szóló korábbi koncepciókban rendre megjelentek már. Az átsorolási feltételek között pedig szintén gazdálkodási jellegüek szerepeltek, például az, hogy a saját bevétel együttesen legalább három éven át egyharmadot meghaladó arányú legyen. A minisztérium a törvény erejénél fogva rárótt kötelezettségének megfelelve elvégezte az átsorolásokat, ám egyetlen intézmény sem kezdeményezte a vállalkozói közintézetté való átsorolást: mind közintézmény lett.

Ez akár tekinthető a konstrukció kudarcának és így a korábbi hasonló jellegü kezdeményezések visszamenőleges kritikájának is, ám az intézmények passzivitására magyarázatot jelenthet $a z$ is, hogy a törvény szerint a vállalkozó közintézetté válás esetében kötelező egy vezető testület létrehozása, amely konstrukciót az intézmények a 2005-ös törvény esetében sikerrel támadták meg az Alkotmánybíróságnál; illetve az ekkor már nyíltan kormányzásra készülő - és arra esélyesnek is tartott - parlamenti ellenzék jelezte: nem ért egyet ezzel az átalakulási iránnyal. És valóban, 2010 nyarán, rögtön kormányra kerülés után, az új parlamenti többség az államháztartási törvény módosítása keretében hatályon kívül helyezte a Kt.-t, ${ }^{11}$ és lényegében visszaállt a 2008 elötti státus.

\section{A 2010-es évek}

Amíg az előző időszak törekvései láttathatók úgy is, mint az állami szerepvállalás csökkentését, távolítását támogató csoportok meg-megújuló küzdelme az azt ellenző

39/2006. (IX. 27.) AB határozat a felsőoktatásról szóló 2005. évi CXXXIX. törvény módosításáról szóló, az Országgyưlés 2006. július 24-i ülésnapján elfogadott törvény 2. § (1) bekezdése - a felsőoktatásról szóló 2005. évi CXXXIX. törvény 25. § (1) bekezdésének a) pontját megállapító része - alkotmányellenességéről

10 2008, évi CV. törvény a költségvetési szervek jogállásáról és gazdálkodásáról

11 2010. évi XC. törvény egyes gazdasági és pénzügyi tárgyú törvények megalkotásáról, illetve módosításáról; 66. §. (1) bek. a) pont 
csoportokkal (még ha a csoportok nem feltétlenül azonos körökből kerültek is ki, azaz kontinuitás nem feltétlenül áll fenn az egyes javaslatok, ellenállások, újabb fordulatok között), addig a Kt. 2010-es kivezetése után az intézmények központi, kormányzati mikromenedzsmentjének megerősödése következett. Ebben az időszakban nyertek egyre nagyobb ellenjegyzési hatáskört a pénzügyminisztériumi alkalmazásba került gazdasági főigazgatók, jelentek meg a költségvetési felügyelők, majd a kancellárok, illetve állandósult a különböző ellenőrző szervek (Állami Számvevőszék, Kormányzati Ellenőrzési Hivatal, fenntartó minisztérium pénzügyi területe) szinte folyamatos vizsgálati jelenléte az intézményekben. Ebben a közegben tette közzé a kiemelt kormányzati beruházásként induló campusátépítésének szakmai előkészítő dokumentumát a Moholy-Nagy Müvészeti Egyetem (Kopek et al. 2015). Az Integrált Intézményfejlesztési Programban az egyetem a szakmai víziók és fejlesztések kidolgozásával párhuzamosan szervezetfejlesztő tanácsadók bevonásával elemezte a beruházás révén jelentősen megnövekvő és számos új funkcióval is bővülő leendő campus müködtetésnek alternatíváit, és arra jutott, hogy az államháztartáson kívül látja csak megvalósíthatónak az új funkcióegyüttes célszerủ és hatékony üzemeltetését. „A z alapvető kérdés, hogy a felsőoktatási szektor szabályozási környezete, fenntartói attitüdje milyen mértékben teszi lehetővé a MOME számára, hogy rugalmas, innovatív, társadalmi és piaci igényekre reflektáló központként tudjon müködni. A célorientáltság és a megvalósíthatóság szempontjából a jelenlegi (tradicionális) müködési modellel a MOME céljai és jövőbeli stratégiája nehezen egyeztethetők össze. [A MOME feltételezi, hogy] vagy pilot jelleggel, vagy egy új intézményi müködési forma definiálásával a fenntartó lehetőséget teremt a felsőoktatási alapfeladatok társasági formában történő ellátására [kísérleti modell]” (p. 65). „A modellváltás olyan kísérletnek tekintendő, amelynek tapasztalatai fontos hozadékot jelenthetnek mind az állam mint fenntartó, mind a többi felsőoktatási intézmény számára. Nem magánvállalkozásként tekintünk a kreatív központra, hanem olyan vegyes fenntartású egyetemre, amelynek tulajdonosi testületében az állami fenntartó képviselői, delegáltjai mellett legnagyobb partnereink szempontjainak megjelenítésére hivatott képviselők is helyet kapnak" (p. 69-70).

A felsőoktatás irányításáért felelős államtitkár tárgyalásokat kezdett a MOME-val egy modellváltási mintaprojektről. A minisztériumban 2016 elején szabályozási koncepciót dolgoztak ki (EMMI 2016), amely a köznevelés, a felsőoktatás, az egészségügy, a szociális ellátások, a kultúra és a sport területére vonatkozóan vázolta fel az állami humán-közszolgáltatások átalakításának egy lehetséges új irányát. A koncepció kettős szabályozási irányt vázolt: megfogalmazta egy költségvetési közintézet és egy köztestületi közintézet kereteit. Előbbi a költségvetési szférán belül maradt volna, utóbbi az államháztartás rendszerén kívülre került volna (szabad vagyongazdálkodási rendszerrel, forrásbevonó képességgel rendelkezik, munkavállalókat foglalkoztat, a kincstári bérszámfejtési rendszerben nem vesz részt stb.). Bár ezt a koncepciót hamar félretették, az államtitkár további intézményekkel is tárgyalásokat kezdett a kísérlethez csatlakozásról, és szakértői csoportok kezdtek el részletes modellváltozatokat kidolgozni, értékelni jogi, vagyongazdálkodási, finanszírozási szempontokból. 2018 elejére elkészült egy terjedelmes háttéranyag (Czermann et al. 2018). A koncepció - miközben leszögezte, hogy a felsőoktatási intézmény közfeladatot lát el - különböző működési modelljavaslatokat írt le és értékelt. Ezek között szerepel az alapítványi forma, a gazdasági társasági forma, az alapítói jogokat gyakorló felsőoktatási intézményi forma és a költségvetési közintézeti forma. Míg ez utóbbi az államháztartás rendszerén belüli müködést jelentene 
új felsőoktatási jogalany definiálásával, addig az előzőek az államháztartás rendszerén kívüli müködést tesznek lehetővé. Az alternatívákat a folyamatba vont intézményekkel folyamatosan egyeztették.

A fenti folyamathoz képest szinte előkészítetlenül és váratlanul jelent meg 2018 szeptemberében az a kormányhatározat, ${ }^{12}$ amelyik a Budapesti Corvinus Egyetem fenntartóváltásáról és törvény előkészítéséről rendelkezett egy fenntartó alapítvány létrehozása érdekében. A cél egy új müködési modell előkészítése és rugalmasabb intézményi működés lehetővé tétele volt. A háttérben szakértői előkészítő munka kezdődött egy új intézményi jogállás kialakításáról. A szúkebb és tágabb szakmai közvéleményt azért is lephette meg ez a döntés, mert már kilenc éve nem volt - a fent említett nagyon szűk intézményi kör vezetőit leszámítva - egyeztetés, vita az intézményi státusról - ami a leghosszabb ilyen periódus volt az elmúlt 30 évben. Az előkészítés nyomán az Országgyúlés 2019 áprilisában módosította ${ }^{13}$ a felsőoktatási törvényt, amelynek egyik fontos változtatása, hogy az állami felsőoktatási intézmény „fenntartói joga mint vagyoni értékű jog - a Kormány külön engedélyével - a Kormány által létrehozott alapítványra átruházható” (6.§). A törvény egyben a $B C E-t$ a magán felsőoktatási intézmények közé sorolta át. A változtatás indoklásaként az előterjesztés ${ }^{14}$ a felsőoktatás nemzetközi versenyképességének növelését, a támogatás felhasználásának eredményességét és társadalmi hasznosságának javítását jelölte meg. Pár nappal később pedig megjelent a törvény a BCE-t fenntartó alapítvány létrehozásáról és a vagyonjuttatásról. ${ }^{15}$

A BCE átalakulásával összefüggésben az innovációs és technológiai miniszter (aki korábban az EMMI oktatási szakállamtitkára volt) és az EMMI oktatási szakállamtitkára is úgy nyilatkozott, ${ }^{16}$ hogy az első intézményi modellkísérletek tapasztalatai alapján a modellváltás akár az összes állami felsőoktatási intézményre kiterjedhet. Jelen tanulmány írásának időpontjában hat további állami egyetem ${ }^{17}$ modellváltásával kapcsolatos előterjesztései várnak kormánydöntésre.

\section{A tervek és megvalósulásuk sajátosságai}

A hazai felsőoktatási intézményi működési keretek átalakításával kapcsolatos tervek és azok megvalósításának áttekintése több szembeötlő sajátosságot is mutat (lásd az 1. áttekintő táblát a Mellékletben). Egyrészt a müködés kereteinek megváltoztatása mögött álló indokok egy jelentős része többnyire állandóan jelen van (szabadabb gazdál-

12 1459/2018. (IX. 25.) Kormányhatározat a Budapesti Corvinus Egyetem fenntartói feladataival kapcsolatos egyes kérdésekről

13 2019. évi XIX. törvény (IV. 3.) a nemzeti felsőoktatásról szóló 2011. évi CCIV. törvény módosításáról

14 T/4516 számú törvényjavaslat a nemzeti felsőoktatásról szóló 2011. évi CCIV. törvény módosításáról; Budapest, 2019, február

15 2019. évi XXX. törvény (IV.11.) a Maecenas Universitatis Corvini Alapítványról, a Maecenas Universitatis Corvini Alapítvány és a Budapesti Corvinus Egyetem részére történő vagyonjuttatásról

16 A Corvinuson indult folyamatot az egész felsőoktatásra szükséges kiterjeszteni. https://www.kormany. $\mathrm{hu} / \mathrm{hu} /$ innovacios-es-technologiai-miniszterium/hirek/a-corvinuson-indult-folyamatot-az-egeszfelsooktatasra-szukseges-kiterjeszteni

17 Amennyire a nyilvánosságra került információk alapján rekonstruálható, ezek: az Állatorvostudományi Egyetem, a Moholy-Nagy Múvészeti Egyetem, a kecskeméti Neumann János Egyetem, a Semmelweis Egyetem, a győri Széchenyi István Egyetem és a Testnevelési Egyetem. A kézirat zárásának időpontjában a vonatkozó kormányhatározatokat még nem adták ki. 
kodás, a közpénzek hatékonyabb felhasználása, a közfeladatok jobb ellátása, a gazdasági partnerekkel való rugalmasabb együttmüködés lehetősége, a vagyonnal való felelős gazdálkodás, a saját források bevonásának képessége stb.), más részük azonban rendre változik, ahogy az oktatáspolitika nézőpontja, aktuális érdeklődése, illetve olyan, idővel változó folyamatok, mint a felsőoktatás funkcióbővülése, a harmadik misszió felerősödése, az intézmények méretének és komplexitásának fokozódása, az intézmények saját bevételi hányadának változása, a müködés fokozódó bürokratizálódása, a jogszabályi korlátok és előírások (Kováts 2012) azt előtérbe helyezik. A felsőoktatás-politika fő napirendje is különböző volt egyes időszakokban, így más gondolkodási közegben, eltérő „fénytörésben” kerültek elő a státusváltással kapcsolatos felvetések: a kilencvenes évek elején a vagyon kezelése, az ágazati szabályozás kialakítása, az évtized második felében az intézményhálózat koncentrálása, azaz az integráció volt meghatározó gondolkodási keret. A 2000-es évek közepén az európai felzárkózás, a Bologna-folyamat képzésszerkezeti és minőségfejlesztési célkitüzéseinek működésoldali támogatása, az évtized végén az államháztartás intézményrendszerének újraszabályozása került az érvelés fókuszába. A legutóbbi felvonásban ismét az intézményi mozgástér növelése, az állami szerepvállalás visszahúzódása, a gazdasági partnerek és érintettek nagyobb szerepvállalásának biztosítása tünik előtérbe kerülni. Az intézmények pedig rendre „béklyóiktól szabadulnának" a rájuk nehezedő különböző elvárások (saját bevétel növelése, nagyobb, komplex intézmények müködésének menedzselése, külső partnerekkel való együttmüködés, munkaerőpiaci elvárásokra tekintettel lévő rugalmasabb képzések müködtetése, nemzetközi versenytérben való helytállás stb.) teljesítése érdekében. Ugyanakkor a változatos tematikák mögött nem látszik előkerülni és tisztázódni az állam és a felsőoktatás kapcsolatának víziója.

$\mathrm{A} z$ is sajátossága ugyanis e néhány évtizedes történetnek, hogy a müködési keretekről való gondolkodás leginkább az irányítás, a kormányzás és szervezetalakítás, a vezetési rendszerek, a finanszírozás és gazdálkodás kérdéseivel kapcsolódik össze. Miközben ez nem szükségszerü. Nem, vagy ritkán merülnek fel az akadémiai szabadsággal, az intézményi autonómiákkal, az állam és felsőoktatás szerepviszonyaival kapcsolatos megfontolások.

Abban is sajátos e történet, hogy elsősorban megvalósulatlan koncepciók, torzóban maradt stratégiák vagy elvetélt állami rendszeralakítási szándékok kísérik. A két tucatnál is több vízióra, jogszabálykoncepcióra mindössze két kihirdetett jogszabály jut (a 2008-as státustörvény és a 2019-es felsőoktatási törvénymódosítás). Jóval szélesebb perspektívában, és nem kifejezetten ezzel a szándékkal, de ugyanerre mutatott rá az elmúlt három évtized felsőoktatási stratégiáinak és jogszabályainak átfogó feldolgozása és párhuzamos közlése is (Veres 2016a, 2016b). Mindez arra is utal, hogy a szakpolitika-tervezés és az implementáció között évtizedeket átívelö, komoly szakadék húzódik - akár az egyik előkészítetlensége, akár a másik gyengesége okán. A különböző kormányzati szereplők, lobbicsoportok, intézményi érdekszövetségek sikerrel avatkoztak közbe, akadályozták meg vagy terelték el a szándékokat a megvalósulástól.

A különböző időszakok dokumentumai körüli viták azt is megmutatják, hogy a különböző szereplők, érintett csoportok eltérő szempontok mentén gondolkodnak a müködési keretek megváltoztatásáról (lásd a 2. áttekintő táblát a Mellékletben). A kormányzat költségvetésért felelős minisztériuma a gazdálkodás kézben tartása mellett az állami támogatás magánforrásokkal történő (részbeni) kiváltását tekinti célnak, valamint a ha- 
tékonyabb, célszerű felhasználást - és kockázatnak tekinti a támogatások pazarló, nem célnak megfelelő felhasználását, amit gyakori ellenőrzésekkel igyekszik megelőzni. Az intézmények irányításért felelős és a fenntartói feladatokat ellátó kormányzati képviselők rugalmasabb működést, a mindhárom missziós területen végzett tevékenységek magas minőségét szeretnék elérni - és a működés feletti kontrollvesztést, a napi ügyekre való befolyásvesztést érzékelik kockázatosnak, amivel szemben az állam jelenlétét, müködési információkkal való ellátását tartják megfelelőnek. Az állami vagyonért felelős kormányzati képviselők a vagyon megóvását tekintik fontosnak - és a vagyonvesztést tekintik valós veszélynek, ami miatt a vagyonátadást igyekeznek megakadályozni.

Ahogy a kormányzaton belül, úgy az intézményekben sem homogének az érdekviszonyok. Az intézmények vezetői a nagyobb működési mozgásteret, gazdálkodási szabadságot keresik, a bürokratikus és adminisztratív korlátok és terhek csökkentését szeretnék, az egyszerübb döntéshozatali eljárásokat, a szervezetfejlesztés és az emberi erőforrás-gazdálkodás korszerű formáit alkalmaznák - miközben igyekeznek kivédeni a fenntartó (delegáltakon keresztül érvényesített) túlzott befolyásszerzését, csökkenteni a finanszírozási és tervezési bizonytalanság okozta kiszolgáltatottságot. Ök a vezetőkiválasztási, hatalomgyakorlási mechanizmusok átalakulásával a befolyáscsökkenéstől is tarthatnak, és könnyen a fenntartó és az akadémiai testület eltérő döntéshozatali logikái közé szorulhatnak.

A z oktatók, kutatók, valamint az intézményi szakapparátus magasabb jövedelmet, jobb munkakörülményeket, profi menedzsmentet, javuló belső szolgáltatásokat és csökkenő adminisztratív terhet vár - és kockázatnak tekinti a piaci logikák eluralkodását az akadémiai értékek felett (menedzserizmus), a közalkalmazotti státus védelmének elvesztését, a teljesítményelv túlzott előtérbe kerülését és a vezetői túlhatalom kialakulását.

Mivel minden szereplő másféle előnyökkel és kockázatokkal számol, és a legtöbbször hiányzik a nyílt és hatékony egyeztetés, az érdekkiegyenlítő mechanizmusok működése és nem utolsósorban: az egymás iránti bizalom, a különböző koncepciók, stratégiák, jogszabály-előkészítő folyamatok során indított lobbik, érdekvédő folyamatok könnyen kiolthatták egymást.

Fontos azt is figyelembe venni, amire Polónyi (2009) hívja fel a figyelmet, hogy az autonóm intézményi gazdálkodás lehetősége - de hozzátehetjük: a 3. misszió kiteljesítése, vagy újabban az innovációs szakpolitikának az intézmények gazdasági folyamatokba való mélyebb bekapcsolódására irányuló igényének vállalása ${ }^{18}$ - egyaránt a piaci müködési logikák irányába hat, miközben az egyetemek akadémiai közösségei a tudományos reputációra orientálódva müködnek. A „szolgáltató” vagy „vállalkozói” egyetemi működési jelleg megjelenése ugyan alátámaszthatja az autonóm gazdálkodás, az ezt biztosító státusváltás igényét, azonban kérdés, hogy ezzel hogyan kerül konfliktusba az akadémiai értékek ápolása (Hrubos 2006), illetve az akadémiai értékek fenntartását egy ilyen váltás hogyan módosítja. Bár az irányítási, vezetési és döntéshozatali rendszerek aprólékos tervezése talán épp az eltérő értékekből fakadó potenciális konfliktusoknak a kezelhetőségére igyekszik megoldást találni, az értékekről, azok megítéléséről és együttélésének esélyeiről a korábbi kezdeményezések során sem volt, és jelenleg, a kísérletbe vont

18 Ennek egyik látványos kifejeződése a felsőoktatás irányítási és az állami intézmények fenntartási feladatainak átkerülése az EMMI-től az ITM-hez. 
intézmények körében sincs vita, egyeztetés; ami előrevetíti azt, hogy esetről esetre vonuló konfliktusok sorozata mentén alakul ki és stabilizálódik majd a státusváltó intézmények működése, kormányzási és döntési rutinja.

A működési keretek átalakításával kapcsolatos felvetések gyakori megjelenése a konfliktusok felelevenítése ellenére is termékeny lehet, amennyiben erősíti a gondolkodást, a reflexiót az állam és a felsőoktatás társadalmi szerepéről, az egyes érintett társadalmi csoportok és szereplők feladatáról, és segít megismerni az eltérő álláspontokat, várakozásokat és félelmeket. Ha nem is rövid távon és konfliktusmentesen, de ezek a viták segíthetnek jobb működési keretek megtalálásában és kialakításában.

\section{IRODALOM}

Barakonyi K. (2009) Felsőoktatási stratégiaalkotás és kormányzás. In: Drótos Gy. \& Kováts G. (eds) Felsőoktatás-menedzsment. Budapest, Aula. pp. 87-108.

Clark, B. R. (1983) The Higher Education System. Berkeley, University of California Press.

Clark, B. R. (1998) Creating Entrepreneurial Universities. Organizational Patbways of Transformation. Paris, Pergamon Press.

Czermann J., Ambrus S., Firneisz M., Gál A. L., Halasi J., Kádár-Csoboth P., Kovács M., Manheim I., Mártai A., Nagy D., Németh Cs., Országh Á., Pachner R. \& Verbói A. T. (2018) A XXI. századi magyar tudásipar megalapozása - müködési modellváltás lehetséges irányai. Budapest, Gál és Társai Ügyvédi Iroda, IFUA Horváth \& Partners, Századvég Gazdaságkutató Rt. és Nabago Kft., 2018. március 31. Kézirat.

CSEFT (2003) A magyar felsöoktatás modernizációját, az Európai Felsőoktatási Térséghez történö csatlakozását célzó felsőoktatás-fejlesztés koncepciója. Vitaanyag (7. változat). Budapest, Oktatási Minisztérium. 2003. december 10. Kézirat.

Derényi A. \& Temesi J. (2016, ed.) A magyar felsőoktatás 1988 és 2014 között. Budapest, Oktatáskutató és Fejlesztő Intézet.

EMMI (2016) Szabályozási koncepció az állami bumán-közszolgáltatások intézményrendszereinek átalakitására, egységesitésére. Tervezet. Budapest, Emberi Erőforrás Minisztérium. Kézirat.

Eтzкоwiтz, H. (1997) The Entrepreneurial University and the Emergence of Democratic Corporatism. In: H. Etzkowitz \& L. Leydesdorff (eds) Universities and the Global Knowledge Economy. The Triple Helix of University-Industry-Government Relations. London and Washington, Pinter. pp. 141-152.

Geréby Gy. et al. (1995) Feljegyzés a felsőoktatás átalakitásáról. Vitaanyag. Kézirat.

Gronitzka, A., Massen, P. \& de Boer, H. (2017) Change in University Governance Structures in Continental Europe. Higher Education Quarterly, Vol. 71. No. 3. Special issue. pp. 274-289.

Нrubos I. (2006) A 21. század egyeteme. Educatio, Vol. 15. No. 4. pp. 665-683.

Király T. ET AL. (1991) Koncepció a felsőoktatási törvény szabályozásához. (Tervezet.) Felsőoktatási Törvényelőkészítő Bizottság. Magyar Felsőoktatás, Vol. I. No. 1. pp. 4-19.

Kopek G., Barcza D., Derényi A., Halasi R. M., Juhász Á. \& Kovács Dániel (2015) Integrált Intézményfejlesztési Program I. kötet. MOME Laboratory - Kreatív Innovációs Tudáspark. Budapest, Moholy-Nagy Művészeti Egyetem. 
Kováts G. (2012) Intézményirányítás - a stratégiai szemléletmód esélyei. In: Hrubos I. (ed.) Elefántcsonttoronyból világitótorony. A felsőoktatási intézmények misszióinak bövülése, átalakulása. Budapest, Aula. pp. 245-292.

MKM (1994) A felsőoktatás-fejlesztési törvény/korm.rend. koncepció tervezete. Kézirat.

MKM (1997) A felsőoktatás fejlesztésének középtávú stratégiája 1997. Budapest, Művelődési és Közoktatási Minisztérium.

MKM (1998) A Müvelödési és Közoktatási Minisztérium 1994-98 között végzett tevékenységéröl készült beszámoló. 1998. február 17. Kézirat.

MUP (2004a) A Magyar Universitas Program és az új felsöoktatási törvény koncepciója. Oktatási Minisztérium, Budapest, 2004. február. Kézirat.

MUP (2004b) Elöterjesztés a Kormány részére a Magyar Universitas Programról, valamint az új felsőoktatási törvény koncepciójáról. Oktatási Miniszter, Igazságügy-Miniszter. Budapest, 2004. április. Kézirat.

OM (2002) Javaslat a magyar felsőoktatás akadémiai reformjára. Budapest, Oktatási Minisztérium, Felsőoktatási Államtitkárság. Kézirat.

Polóny I. (2009) A hazai felsőoktatás gazdasági működése, szerveződése és vezetése a 2000-es évek legelején. Új Pedagógiai Szemle, Vol. 2009. Nos 8-9. pp. 3-26.

Price Waterhouse (1995) Bemutatkozó tanulmány. Budapest. Kézirat.

Szalai Á. (2004) A felsőoktatás intézményi keretei: intézményi státus és működés, intézményfinanszírozás. In: Temesi J. (ed.) Finanszírozás és gazdálkodás a felsőoktatásban. Budapest, Aula.pp. 344-441.

Szolár É. (2010) A felsőoktatás reformja és a Bologna folyamat Magyarországon. Magyar Pedagógia, Vol. 110. No. 3. pp. 239-263.

Temesi J. (2016) A magyar felsőoktatás változásai 1988 és 2014 között: trendelemzések előkészítése a szakirodalom alapján. In: Derény i A. \& Temesi J. (eds) A magyar felsőoktatás 1988 és 2014 között. Budapest, Oktatáskutató és Fejlesztő Intézet. pp. 53-80.

van Vaught, F. \& de Boer, H. (2015) Governance Models and Policy Instruments. In: J. Huisman, H. de Boer, D. D. Dill \& M. Souto-Otero (eds) The Palgrave International Handbook of Higher Education Policy and Governance. Houndmills (UK), Palgrave Macmillan. pp. 38-56.

Veres P. (2016a) Az 1998-2014 közötti korszak áttekintése a felsőoktatási stratégiai dokumentumok alapján. In: Derényi A. \& Temesi J. (eds) A magyar felsőoktatás 1988 és 2014 között. Budapest, Oktatáskutató és Fejlesztő Intézet. pp. 13-36.

Veres P. (2016b) Stratégiai irányok és irányváltások a felsőoktatási jogszabályok alapján, 1988-2014. In: Derényi A. \& Temesi J. (eds) A magyar felsőoktatás 1988 és 2014 között. Budapest, Oktatáskutató és Fejlesztő Intézet. pp. 37-51.

\section{Hivatkozott jogszabályok, kormánybatározatok}

1993. évi LXXX. törvény a felsőoktatásról

1996. évi LXI. törvény a felsőoktatásról szóló 1993. évi LXXX. törvény módosításáról

1999. évi LII. törvény a felsőoktatási intézményhálózat átalakításáról, továbbá a felsőoktatásról szóló 1993. évi LXXX. törvény módosításáról

2008. évi CV. törvény a költségvetési szervek jogállásáról és gazdálkodásáról

2010. évi XC. törvény egyes gazdasági és pénzügyi tárgyú törvények megalkotásáról, illetve módosításáról 
T/4516 számú törvényjavaslat a nemzeti felsőoktatásról szóló 2011. évi CCIV. törvény módosításáról; Budapest, 2019. február

2019. évi XIX. törvény (IV. 3.) a nemzeti felsőoktatásról szóló 2011. évi CCIV. törvény módosításáról

2019. évi XXX. törvény (IV. 11.) a Maecenas Universitatis Corvini Alapítványról, a Maecenas Universitatis Corvini Alapítvány és a Budapesti Corvinus Egyetem részére történő vagyonjuttatásról

107/1995. (XI. 4.) OGY határozat a felsőoktatás fejlesztésének irányelveiről

1049/1996. (V. 22.) Korm. határozat a felsőoktatás fejlesztésének irányelveiről szóló 107/1995. (XI. 4.) OGY határozat végrehajtását szolgáló feladattervről és jogalkotási programról

1459/2018. (IX. 25.) Korm. határozat a Budapesti Corvinus Egyetem fenntartói feladataival kapcsolatos egyes kérdésekről

39/2006. (IX. 27.) AB határozat a felsőoktatásról szóló 2005. évi CXXXIX. törvény módosításáról szóló, az Országgyűlés 2006. július 24-i ülésnapján elfogadott törvény 2 . \ (1) bekezdése - a felsőoktatásról szóló 2005. évi CXXXIX. törvény 25. \$ (1) bekezdésének a) pontját megállapító része - alkotmányellenességéről. Magyar Közlöny, Vol. XV. No. 9. pp. 654-659.

\section{MELLÉKLET}

1. tábla: A tervezett új működési keretek áttekintése

\begin{tabular}{|c|c|c|c|c|}
\hline Év & Tervezett új státus & Cél & Dokumentum & Nyilvánosság* \\
\hline 1991 & $\begin{array}{l}\text { köztestület/alapít- } \\
\text { vány }\end{array}$ & $\begin{array}{l}\text { tulajdonviszonyok } \\
\text { rendezése, } \\
\text { önálló gazdálkodás } \\
\text { biztosítása }\end{array}$ & törvénykoncepció & Nyt \\
\hline 1994 & közalapítvány & $\begin{array}{l}\text { saját tulajdon } \\
\text { teljes gazdálkodási } \\
\text { önállóság }\end{array}$ & $\begin{array}{l}\text { felsőoktatás-fejlesztési } \\
\text { koncepció }\end{array}$ & Nny \\
\hline 1995 & közalapítvány & $\begin{array}{l}\text { támogatás mérséklése, } \\
\text { külső források bevo- } \\
\text { nása }\end{array}$ & $\begin{array}{l}\text { felsőoktatás-fejlesztési } \\
\text { országgyülési határozat }\end{array}$ & $\mathrm{j}$ \\
\hline 1996 & közalapítvány & $\begin{array}{l}\text { vegyes finanszírozás- } \\
\text { hoz igazított gazdál- } \\
\text { kodás }\end{array}$ & $\begin{array}{l}\text { szakértői anyagok (pl. } \\
\text { PW) }\end{array}$ & Nny \\
\hline 1997 & nem nevesített & $\begin{array}{l}\text { nagyobb gazdálkodási } \\
\text { szabadság (integrációs } \\
\text { pioníroknak „mézes- } \\
\text { madzag”) }\end{array}$ & $\begin{array}{l}\text { felsőoktatás-fejlesztés } \\
\text { középtávú stratégiája } \\
\text { (MKM) }\end{array}$ & Nyt \\
\hline 2003 & $\begin{array}{l}\text { - speciális költség- } \\
\text { vetési intézmény, } \\
\text { - társasági forma, } \\
\text { - nonprofit szerve- } \\
\text { zet (Kht.) }\end{array}$ & $\begin{array}{l}\text { gyorsabb, rugalmasabb } \\
\text { reagálás intézmények } \\
\text { és rendszerek közötti } \\
\text { versenyben }\end{array}$ & Szakértői CSEFT & Nny \\
\hline
\end{tabular}


1. tábla: (folyt.)

\begin{tabular}{|c|c|c|c|c|}
\hline Év & Tervezett új státus & Cél & Dokumentum & Nyilvánosság* \\
\hline 2004 & $\begin{array}{l}\text { speciális jogállású } \\
\text { költségvetési intéz- } \\
\text { mény }\end{array}$ & $\begin{array}{l}\text { rugalmasabb, piac- } \\
\text { szerűbb működés } \\
\text { lehetősége }\end{array}$ & $\begin{array}{l}\text { OM program (MUP), } \\
\text { kormányelőterjesztés- } \\
\text { tervezet }\end{array}$ & Nyt \\
\hline 2008 & $\begin{array}{l}\text { vállalkozó közin- } \\
\text { tézet }\end{array}$ & $\begin{array}{l}\text { államháztartási rend- } \\
\text { szer megújítása, } \\
\text { átláthatóbb, hatéko- } \\
\text { nyabb közfeladat-ellá- } \\
\text { tás, } \\
\text { költségvetési gazdálko- } \\
\text { dás modernizálása }\end{array}$ & státustörvény & $\mathrm{J}$ \\
\hline 2015 & $\begin{array}{l}\text { - speciális költség- } \\
\text { vetési intézmény } \\
\text { - társasági forma }\end{array}$ & $\begin{array}{l}\text { új campus, új funkciók } \\
\text { megvalósíthatósága: } \\
\text { szabadabb müködés és } \\
\text { gazdálkodás }\end{array}$ & $\begin{array}{l}\text { MOME Integrált } \\
\text { Intézmény-fejlesztési } \\
\text { Program (kötet) }\end{array}$ & $\mathrm{Ny}$ \\
\hline 2016 & $\begin{array}{l}\text { - költségvetési köz- } \\
\text { intézet } \\
\text { - köztestületi köz- } \\
\text { intézet }\end{array}$ & $\begin{array}{l}\text { rugalmasabb működés, } \\
\text { szabad vagyongazdál- } \\
\text { kodás, forrásbevonás }\end{array}$ & EMMI belső anyag & Nny \\
\hline 2018 & $\begin{array}{l}\text { - alapítói jogokat } \\
\text { gyakorló egyetem } \\
\text { - felsőoktatási } \\
\text { közintézet } \\
\text { - alapítványi/gaz- } \\
\text { dasági társasági } \\
\text { fenntartású intéz- } \\
\text { mény }\end{array}$ & $\begin{array}{l}\text { közfeladat jobb ellátá- } \\
\text { sa, rugalmasabb múkö- } \\
\text { dés, vagyongazdálko- } \\
\text { dás, forrásbevonás }\end{array}$ & $\begin{array}{l}\text { EMMI / ITM szakér- } \\
\text { tői anyagok }\end{array}$ & Nny \\
\hline 2018 & $\begin{array}{l}\text { új működési modell } \\
(\mathrm{BCE})\end{array}$ & $\begin{array}{l}\text { magyar felsőoktatási } \\
\text { intézményrendszer és } \\
\text { környezetének meg- } \\
\text { erősítése }\end{array}$ & kormányhatározat & $\mathrm{j}$ \\
\hline 2019 & $\begin{array}{l}\text { vagyonkezelö ala- } \\
\text { pítvány által fenn- } \\
\text { tartott felsőoktatási } \\
\text { intézmény (BCE) }\end{array}$ & $\begin{array}{l}\text { nemzetközi verseny- } \\
\text { képesség növelése, } \\
\text { a támogatás felhasz- } \\
\text { nálásának eredmé- } \\
\text { nyessége, társadalmi } \\
\text { hasznosulása }\end{array}$ & $\begin{array}{l}\text { törvények és Nftv. } \\
\text { módosítás }\end{array}$ & $\mathrm{J}$ \\
\hline
\end{tabular}

*Jelmagyarázat: $\mathrm{Nny}=$ nem nyilvános anyag; $\mathrm{Nyt}=$ nyilvános tervezet; $\mathrm{J}=$ jogszabály; $\mathrm{j}=$ parlamenti, kormányzati határozat 
2. tábla: A különböző szereplők által várt előnyök és vélt kockázatok áttekintése

\begin{tabular}{|c|c|c|}
\hline Szereplök & Várt előnyök & Felvetett kockázatok \\
\hline \multicolumn{3}{|l|}{ Kormányzat } \\
\hline $\begin{array}{l}\text { - költségvetésért felelős } \\
\text { minisztérium }\end{array}$ & $\begin{array}{l}\text { állami támogatás (részbeni) } \\
\text { kiváltása magánforrásokkal; } \\
\text { hatékonyabb, célszerű gazdál- } \\
\text { kodás }\end{array}$ & $\begin{array}{l}\text { támogatásfelhasználás pazarló, } \\
\text { nem célszerú módja }\end{array}$ \\
\hline - vagyonért felelős min. & & vagyonvesztés \\
\hline $\begin{array}{l}\text { - irányításért és intéz- } \\
\text { ményfenntartásért } \\
\text { felelős minisztérium } \\
\end{array}$ & $\begin{array}{l}\text { rugalmasabb működés, } \\
\text { jó minőség mindhárom misz- } \\
\text { szióban }\end{array}$ & $\begin{array}{l}\text { működés feletti kontrollvesztés, } \\
\text { befolyáscsökkenés }\end{array}$ \\
\hline \multicolumn{3}{|l|}{ Intézmények } \\
\hline - vezetői & $\begin{array}{l}\text { nagyobb működési mozgástér, } \\
\text { nagyobb gazdálkodási önállóság, } \\
\text { bürokratikus és admin. korlátok } \\
\text { és terhek csökkenése, } \\
\text { egyszerübb döntéshozatali rend, } \\
\text { jobb lehetőség szervezetfejlesz- } \\
\text { tésre, } \\
\text { HR menedzsment / teljesít- } \\
\text { ményelv }\end{array}$ & $\begin{array}{l}\text { fenntartó (delegáltak) túlzott } \\
\text { befolyása (révén túlzott állami } \\
\text { kontroll), } \\
\text { finanszírozási bizonytalanság, } \\
\text { kiszolgáltatottság, } \\
\text { vezetői pozíció átalakulása (két } \\
\text { túz között), } \\
\text { választási, hatalomgyakorlási } \\
\text { mechanizmusok átalakulása, } \\
\text { befolyáscsökkenés }\end{array}$ \\
\hline - oktatók, szakapparátus & $\begin{array}{l}\text { magasabb jövedelem, } \\
\text { kisebb állami kontroll, } \\
\text { profibb menedzsment, } \\
\text { csökkenő adminisztráció, } \\
\text { jobb szolgáltatások }\end{array}$ & $\begin{array}{l}\text { piaci logikák eluralkodása az } \\
\text { akadémiai értékek felett, } \\
\text { közalkalmazotti státus (védelem) } \\
\text { elvesztése, } \\
\text { teljesítményelv elötérbe kerülése, } \\
\text { túlzott vezetői hatalom, mene- } \\
\text { dzserizmus }\end{array}$ \\
\hline
\end{tabular}

A cikk a Creative Commons Attribution 4.0 International License (https://creativecommons.org/licenses/ by/4.0/) feltételei szerint publikált Open Access közlemény, melynek szellemében a cikk bármilyen médiumban szabadon felhasználható, megosztható és újraközölhető, feltéve, hogy az eredeti szerző és a közlés helye, illetve a CC License linkje és az esetlegesen végrehajtott módosítások feltüntetésre kerülnek. (SID_1) 